Note

\title{
TERMITE (INSECTA, ISOPTERA) FAUNA FROM NATIONAL PARKS OF THE NORTHEAST REGION OF ARGENTINA
}

\author{
Enrique Rafael Laffont*; Gladys Josefina Torales; Juan Manuel Coronel; Manuel Osvaldo \\ Arbino; María Celina Godoy \\ Facultad de Ciencias Exactas y Naturales y Agrimensura, Universidad Nacional del Nordeste. Av. Libertad 5400. \\ C.P. 3400 - Corrientes - Argentina. \\ *Corresponding author <erl@exa.unne.edu.ar>
}

\begin{abstract}
The knowledge of insect biodiversity in natural areas of Argentina is limited, and termites are among the understudied taxa. In order to assess the diversity of Isoptera in some protected areas of the country, termite sampling within three National Parks of the Northeast region of Argentina was developed during 1995-1999. The results presented in this paper correspond to the Chaco National Park (Province of Chaco), Iguassu National Park (Province of Misiones) and Mburucuya National Park (Province of Corrientes). Among the four termite families recorded from Argentina, the family Termitidae was the best represented at the three sampled areas. The recorded genera (15) were: Rugitermes Holmgren and Tauritermes Krishna (Kalotermitidae), Heterotermes Frogatt (Rhinotermitidae), Cornitermes Wasmann, Cortaritermes Mathews, Diversitermes Holmgren, Nasutitermes Dudley, Velocitermes Holmgren (Nasutitermitinae), Amitermes Silvestri, Microcerotermes Silvestri, Neocapritermes Holmgren, Termes Linné (Termitinae), Anoplotermes Müller, Aparatermes Fontes and Ruptitermes Mathews (Apicotermitinae) (Termitidae). None of the collected termite species was common to the three National Parks, and only four of them were detected at two of the reserves. Due to the particular assemblage of termites found at each park, these three natural protected areas could be considered important reserves for the conservation of the termite fauna from the Northeast region of Argentina.
\end{abstract}

Key words: biodiversity, termitological survey, reserves, neotropical region

\section{FAUNA DE CUPINS (INSECTA, ISOPTERA) DE PARQUES NACIONAIS DA REGIÃO NOROESTE DA ARGENTINA}

\begin{abstract}
RESUMO: O conhecimento da biodiversidade de insetos em áreas naturais da Argentina é limitado e os cupins estão entre os menos estudados. Para conhecer a diversidade dos Isóptera em algumas áreas protegidas do país, foi feita uma amostragem de cupins em três parques nacionais da região noroeste da Argentina, durante 1995-1999. Os resultados aqui apresentados correspondem ao Chaco National Park (Província de Chaco), Iguassu National Park (Província de Misiones) e Mburucuya National Park (Província de Corrientes). Entre as quatro famílias de cupins registrados na Argentina, a família dos Termitidae foi a mais bem representada nas três áreas. Os gêneros registrados foram: Rugitermes Holmgren e Tauritermes Krishna (Kalotermitidae), Heterotermes Frogatt (Rhinotermitidae), Cornitermes Wasmann, Cortaritermes Mathews, Diversitermes Holmgren, Nasutitermes Dudley, Velocitermes Holmgren (Nasutitermitinae), Amitermes Silvestri, Microcerotermes Silvestri, Neocapritermes Holmgren, Termes Linné (Termitinae), Anoplotermes Muller, Aparatermes Fontes and Ruptitermes Mathews (Apicotermitinae) (Termitidae). Nenhuma das espécies de cupim coletadas foi comum para os três parques e apenas quatro foram coletadas em duas reservas. Devido ao arranjo particular dos cupins, que foi encontrado em cada parque, estas três áreas naturais protegidas podem ser consideradas como importantes reservas para a conservação da fauna de cupins na região noroeste da Argentina.

Palavras-chave: biodiversidade, levantamento de cupins, reservas, região neotropical
\end{abstract}

\section{INTRODUCTION}

The protection of biodiversity is one of the most relevant issues in global conservation. The first step in order to protect and to manage natural areas is knowledge of the inhabiting organisms. In Argentina, research is needed in order to successfully complete this initial stage, leading to the implementation of decisions about sustainable resource management (Coscarón, 1999). Although insects are among the better known groups of invertebrates from National Parks in Argentina, little data are available about the termite fauna and its ecological 
importance. Previous studies in other countries have shown that termites play a key role as decomposers of organic mater in savannah systems, as well as in tropical soils (Wood \& Sands, 1978; Eggleton et al., 1995; 1996). This group of insects is potentially one of the most important bioindicator taxa, reflecting disturbance, fragmentation or destruction of habitats (Jones \& Eggleton, 2000).

The most recent termitological surveys in Argentina were mainly of those species considered economically important, attacking buildings and trees (Torales, 1995; Torales et al., 1988, 1990, 1995a, 1995b, 1996; Laffont et al., 1998). Torales et al. (1997) presented a taxonomic list of termites from Argentina, with the geographical distribution and feeding habits of most of the 41 species cited. This is the first study dealing specifically with the termite fauna from Natural Protected Areas situated at the Northeast region of the country. Different aspects of the flora and fauna from these areas were previously analysed by Erize et al. (1981), Saibene \& Montanelli (1997), Alvarez et al. (1998), Céspedez et al. (1998), among other authors.

\section{MATERIAL AND METHODS}

Termite sampling was carried out within three Natural Protected Areas from Northeast Argentina: Chaco National Park, Mburucuya National Park and Iguassu National Park, between 1995 and 1999. The approximate distance between Chaco and Mburucuya National Parks is $180 \mathrm{~km}$, and both are roughly $500 \mathrm{~km}$ from Iguassu National Park (Figure 1). In each park, sampling areas were selected along main trails and paths, in an attempt to search through all the recognized vegetation units. Three and six 3-ha sites were delimited at the Chaco and Mburucuya National Parks, respectively. At the Iguassu National Park, six areas of 6 ha were selected. A 1,500

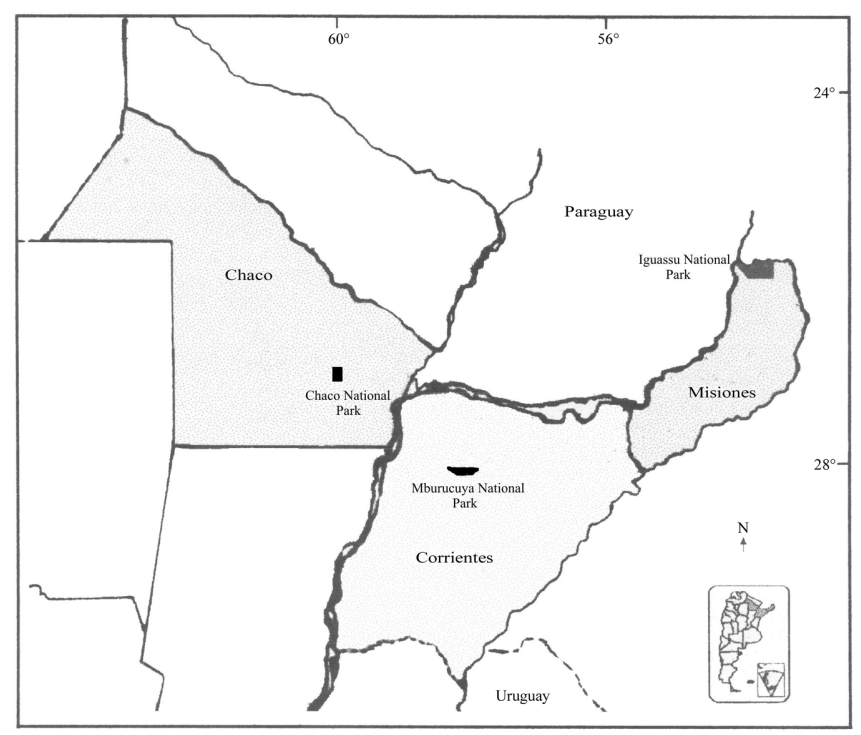

Figure 1 - Location of the Natural protected Areas (NE Argentina). $\mathrm{m} \times 20 \mathrm{~m}$ belt was sampled within each area. At each belt, 15 sampling points of $2 \mathrm{~m} \times 2 \mathrm{~m}$ (with a $100 \mathrm{~m}$. distance among them) were investigated in detail for a total of one person hour (30 minutes each for two workers experienced in termite sampling), searching the following microhabitats: living and dead trees up to $2 \mathrm{~m}$ from ground level, branches and stems fallen on the ground, litter and humus accumulated at the base of the trees, dry dung of herbivorous mammals, as well as pieces of partially buried dead wood. Samples were also taken when arboreal or epigeal nests, tunnels or other termite constructions were recognized closer to the belt. In the case of epigeal nests and mounds, the dimensions and main characteristics were recorded, and insect samples were obtained by opening a small hole on the nest walls. In the cases of arboreal termites, the individuals were taken from nests or other constructions found on trunks or branches. The condition of the inspected decaying wood was also recorded. No traps or baits were used. The sampling protocol, closely related to the traditional inventories or 'museum collecting' style, is considered efficient at maximizing the number of species recorded (Coddington et al., 1991). The total sampling efforts, considering transects and adjacent sites, were 90 person hours (Chaco National Park) and 180 person hours (Mburucuya and Iguassu National Parks), being distributed among the four seasons of the year at each park.

The samples were fixed in FAA (formaldehyde: alcohol: acetic acid, in the proportion 25: 70: 5) and preserved in $80 \%$ ethanol. Specimens were identified by G. J.Torales (Kalotermitidae, Rhinotermitidae and Termitidae, except Apicotermitinae) and M. C. Godoy (Apicotermitinae), using keys and descriptions from Silvestri (1903), Emerson (1952), Krishna (1961), Mathews (1977), Fontes \& Terra (1981), Fontes (1986; 1992), Constantino (1998; 1999; 2000; 2002), and reference to samples in the termite collection at the Facultad de Ciencias Exactas y Naturales y Agrimensura, Universidad Nacional del Nordeste, Corrientes, Argentina (FACENAC), where specimens from different localities of Argentina and Brazil, determined by L.R.Fontes are deposited. For identification, the worker coiling gut and mandibles, as well as soldier characteristics, were considered. Y. Roisin and E. M. Cancello determined the samples of $N$. coxipoensis and $R$. rugosus, respectively.

Cluster analyses were conducted to assess the similarity of species among parks and the extend to which individual parks were representative of the termite diversity of the Northeast region of the country (Dillon \& Goldstein, 1984).

Landscapes and Vegetation Units related to Termite Fauna.

Chaco National Park (surface area: 15,000 hectares): Situated $130 \mathrm{~km}$ northwest from the city of Resistencia (Province of Chaco), at the Capitan Solari 
Department (Figure 1), the park is included in the Eastern Chacoan District, within the sub region of Swamps, Reed Fields and Gallery Forests (Cabrera, 1976). The climate is subtropical and the rainfall reaches an annual mean of 1,200 mm. The gallery forest borders the Negro river, main watercourse within the Park, and at its sides the hardwood forest called "monte fuerte" is situated. Both formations share woody species like Schinopsis balansae Engler, Aspidosperma quebracho blanco Schlecht., Astronium balansae Engler, Patagonula americana L. and Caesalpinia paraguariensis (D. Parodi) Burkart. Only a few relicts of the $S$. balansae forest ("quebrachal"), remains after decades of intensive logging. In the open brush woodlands (arboreal savanna), there is a dominance of Copernicia australis Becc. palm trees (Erize et al., 1981).

Mburucuya National Park (surface area: 15,060 hectares): It is situated at the Mburucuya Department (Province of Corrientes), $150 \mathrm{~km}$. from the city of Corrientes (Figure 1). This area is comprised within the Eastern Chacoan District (Subdistrict of Corrientes) (Cabrera, 1976), and the Mesopotamian park of savannas with gramineous, Butia yatay (Mart.) Becc. palm trees and forests at the inlaid hills and plains (Carnevali, 1994). Three natural regions converge at the Park area: Paranaense, Chaqueña and Espinal. The climate is subtropical or mesotermal and the rainfall, irregularly seasonal, vary between 1,000 and $1,500 \mathrm{~mm}$ per year. The most representative woody plant communities are: the $B$. yatay palm trees with associated gramineous; the hygrophytic forests with Ocotea acutifolia (Nees) Mez. and Enterolobium contortisiliquum (Vell.) Morong. and the subxerophytic forests with E. contortisiliquum and $G$. amorphoides. These communities have been affected by extraction of woods and cattle grazing. The herbaceous communities are savannas of A. lateralis, Paspalum notatum Flügge and Axonopus sp. (Saibene \& Montanelli, 1997).

Iguassu National Park (surface area: 55,000 hectares): Situated at the Northeast region of the Province of Misiones, the Park is close to the city of Puerto Iguazu and belongs to the Paranaense biogeographic province (Figure 1). The warm climate and abundant rainfall $(2,000$ $\mathrm{mm}$ per year) favor the development of the Paranaense Forest, the most biodiverse eco-region in Argentina and of highest priority for conservation. This climax community includes large trees: Myrocarpus frondosus Fr. Allem., Peltophorum dubium (Spreng.) Taub., Apuleia leiocarpa (Vog.) Macbr., Parapiptadenia rigida (Benth.) Brenan, E. contortisiliquum and Patagonula americana; medium height trees: Chrysophyllum gonocarpum (Mart. \& Eichl.) Engl., Ocotea pulchella (Nees) Mez, Nectandra lanceolata Nees, Syagrus romanzoffianum (Cham.) Glassman and tree ferns: Alsophila atrovirens (Langsd. \& Fisch.) (Erize et al., 1981).

\section{RESULTS}

Considering the three sampled Natural Protected Areas, the recorded termite fauna was composed of 15 genera and 26 species (Table 1), most of them (12 genera and 22 species) belonging to Termitidae (higher termites). Among those, the Nasutitermitinae was the bestrepresented subfamily (13 species). The number of termite species collected was higher at the Iguassu National Park (14 species), while the other two areas registered eight species.

In the cluster analysis of relative similarity between species lists, three groups of species were identified, representing a particular set of termites located at each park (Figure 2). The first group included the species located at the Iguassu National Park, the second one grouped the species from Mburucuya National Park and the two species recorded from both areas (Cornitermes cumulans and Neocapritermes opacus). The third group corresponded to the termite species from Chaco National Park and the two species common to Chaco and Mburucuya National Parks (Cortaritermes fulviceps and Nasutitermes aquilinus). The Mburucuya National Park shared two species with each one of the other two reserves (Figure 2). None of the collected termite species was found in all three National Parks, and Iguassu and Chaco National Parks did not share any species. The remaining 22 species came from only one of the studied areas: twelve from the Iguassu National Park, six from the Chaco National Park and four from the Mburucuya National Park.

At the Chaco National Park, only two woodfeeder species, Heterotermes tenuis and Microcerotermes strunckii, were recorded from the relicts of the $S$. balansae forest ("quebrachal"). The arboreal nests of M.strunckii were distributed on trunks and branches at heights of above $3 \mathrm{~m}$, which made very difficult the access to them. From the hard-wood forest ("monte fuerte"), Tauritermes taurocephalus (on C. paraguariensis tree), $H$. tenuis (on S. balansae tree) and N. aquilinus (on A.



Figure 2 - Dendrogram showing the similarities and differences of the termite fauna of the studied places. Average linkage method, Euclidean distance. 
Table 1 - Taxonomic list of termites inhabiting the Chaco National Park (1), Mburucuya National Park (2) and Iguassu National Park (3) (Argentina), with data about collection sites and feeding habits. References: I: inquiline species.

\begin{tabular}{|c|c|c|c|}
\hline & Collection Sites & Feeding habits & Location \\
\hline \multicolumn{4}{|l|}{ Family Termitidae } \\
\hline \multicolumn{4}{|l|}{ Subfamily Nasutitermitinae } \\
\hline $\begin{array}{l}\text { Cortaritermes fulviceps } \\
\text { (Silvestri) }\end{array}$ & $\begin{array}{l}\text { Epigeal nests, fallen stems, galleries on } B . \\
\text { yatay palm stem. }\end{array}$ & $\begin{array}{l}\text { Roots, leaves and stalks of } \\
\text { gramineous, wood. }\end{array}$ & 1,2 \\
\hline Cornitermes cumulans (Kollar) & Epigeal nests, fallen stems. & $\begin{array}{l}\text { Litter, roots and leaves of gramineous, } \\
\text { wood. }\end{array}$ & 2,3 \\
\hline $\begin{array}{l}\text { Diversitermes diversimiles } \\
\text { (Silvestri) }\end{array}$ & Under fallen branches. & Decomposed woody materials. & 3 \\
\hline $\begin{array}{l}\text { Nasutitermes aquilinus } \\
\text { (Holmgren) }\end{array}$ & Arboreal nests, fallen stems. & Wood. & 1,2 \\
\hline $\begin{array}{l}\text { Nasutitermes coxipoensis } \\
\text { (Holmgren) }\end{array}$ & Epigeal nests. & Dead grass. & 2 \\
\hline Nasutitermes sp. 1 & Galleries on living tree stems. & Wood. & 3 \\
\hline Nasutitermes sp. 2 & Fallen branches. & Wood. & 3 \\
\hline Nasutitermes sp. 3 & Galleries on dead tree. & Wood. & 3 \\
\hline Nasutitermes sp. 4 & On fallen stalk. & Wood. & 3 \\
\hline Nasutitermes sp. 5 & Fallen branches. & Wood. & 3 \\
\hline Nasutitermes sp. 6 & Fallen tree. & Wood. & 3 \\
\hline Nasutitermes sp. 7 & Dead tree stem. & Wood. & 3 \\
\hline Velocitermes sp. & Fallen stems. & Roots and leaves of gramineous. & 2 (I) \\
\hline \multicolumn{4}{|l|}{ Subfamily Termitinae } \\
\hline Amitermes amifer Silvestri & Mound, S. balansae log. & $\begin{array}{l}\text { Decomposed woody materials, } \\
\text { decaying wood, litter. }\end{array}$ & 1 \\
\hline $\begin{array}{l}\text { Microcerotermes strunckii } \\
\text { (Soerensen) }\end{array}$ & $\begin{array}{l}\text { Arboreal nests and galleries on living } \\
\text { trees. }\end{array}$ & Wood. & 1 \\
\hline Neocapritermes opacus (Hagen) & In T.saltans nests, under logs. & $\begin{array}{l}\text { Decomposed woody materials, dry } \\
\text { dung. }\end{array}$ & 2,3 \\
\hline Termes saltans (Wasmann) & Epigeal nests. & Humus, decomposed litter. & 2 \\
\hline Termes sp. & Roots of S.balansae fallen tree. & Humus, litter, probably wood. & 1 \\
\hline \multicolumn{4}{|l|}{ Subfamily Apicotermitinae } \\
\hline $\begin{array}{l}\text { Aparatermes cingulatus } \\
\text { (Burmeister) }\end{array}$ & C. fulviceps mounds. & Humus. & 3 (I) \\
\hline Anoplotermes sp. 1 & Inside and under fallen branches. & Humus. & 3 (I) \\
\hline Anoplotermes sp. 2 & Under dry dung. & Humus. & 2 (I) \\
\hline Ruptitermes sp. & Hipogeal sector of $C$. fulviceps mounds. & Litter. & $1(\mathrm{I})$ \\
\hline \multicolumn{4}{|l|}{ Family Kalotermitidae } \\
\hline Rugitermes rugosus (Hagen) & Dead branch of $P$. americana & Wood. & 3 \\
\hline Rugitermes sp. & Dead stem. & Wood. & 3 \\
\hline $\begin{array}{l}\text { Tauritermes taurocephalus } \\
\text { (Silvestri) }\end{array}$ & $\begin{array}{l}\text { Under bark and inside galleries on } \\
\text { branches of dead tree. }\end{array}$ & Wood. & 1 \\
\hline \multicolumn{4}{|l|}{ Family Rhinotermitidae } \\
\hline Heterotermes tenuis (Hagen) & Fallen branch of $S$. balansae. & Wood. & 1 \\
\hline
\end{tabular}

macrocarpa tree) were found on live and dead trees and within decaying wood. Termes sp., also in this sector, was noted attacking exposed $S$. balansae roots (dead tree). The nests of the mound-building species $C$. fulviceps were also located at this area, also inhabited by $H$. tenuis, $A$. amifer and Ruptitermes sp.

At the residential zone of the Park, arboreal nests of $N$. aquilinus and M. strunckii occupied dead and living exotic trees (Eucalyptus sp. and Melia azedarach).
C. fulviceps mounds were also found near the houses. At the Mburucuya National Park, the most striking features at the savannah landscapes were the frequently found epigeal nests of $C$. fulviceps, $C$. cumulans and Termes saltans. Nasutitermes coxipoensis mounds were also occasionally found at these areas. The hygrophytic forest lodged mounds of $C$. fulviceps and C.cumulans, as well as nests of $N$. aquilinus (on decaying logs). At the $B$. yatay palm trees communities, $C$. fulviceps and $T$. saltans 
epigeal nests were present, as well as $N$. opacus, Velocitermes sp. and Anoplotermes sp. 2, located under dry cattle dung or inhabiting the nests constructed by the first two species. The only termite species collected from the subxerophytic forest was $N$. aquilinus, feeding on dead wood.

The termite fauna recorded from the Iguassu National Park was mainly collected within dead wood (stumps and fallen trunks and branches), at the Paranaense Forest (9 species). The only exceptions were the epigeal nests of $C$. cumulans, the galleries occupied by Aparatermes cingulatus within those nests and the constructions of Rugitermes rugosus (on P. americana) and Nasutitermes sp. 3 (on E. contortisiliquum) within branches of living trees. The genus Nasutitermes appeared to be widely distributed within the forests at the Iguassu National Park. The dimensions of the nests and mounds registered from the three parks, for each termite species, are presented in Table 2.

\section{DISCUSSION}

Taking into consideration the total number of termite species previously recorded from each of the three provinces (Torales et al., 1997), more than $25 \%$ of the species registered from the Province of Corrientes are present at the Mburucuya National Park, $64 \%$ of the termites from the Province of Chaco inhabit the Chaco National Park and $43 \%$ of the Isoptera from the Misiones Province are distributed at the Iguassu National Park (Torales et al., 1997).

At the Chaco National Park three of the four families cited from Argentina were collected, while at the Iguassu National Park two of them were present, and only one at the Mburucuya National Park (Torales et al., 1997).

Among the Termitidae, all the termite species with epigeal nests located in the Provinces of Chaco, Corrientes and Misiones are present at these National Parks, as well as the two more commonly found arboreal species from Chaco and Corrientes (N. aquilinus and $M$. strunckii) (Torales, 1998).

Table 2 - Nests and mounds dimensions $(n=10)$ of the termite species recorded from the three sampled areas. $*: \mathrm{n}=6$.

\begin{tabular}{|c|c|c|}
\hline & Height & Diameter \\
\hline & \multicolumn{2}{|c|}{ - } \\
\hline N. aquilinus & $1.39(0.65-2.10)$ & $1.19(0.42-1.80)$ \\
\hline M. strunckii* & $0.44(0.26-0.68)$ & $0.68(0.40-0.93)$ \\
\hline C. cumulans & $0.79(0.45-1.44)$ & $2.75(1.05-3.47)$ \\
\hline C. fulviceps & $0.42(0.19-0.74)$ & $0.99(0.51-1.35)$ \\
\hline T. saltans & $0.29(0.15-0.34)$ & $1.12(0.77-1.35)$ \\
\hline N. coxipoensis & $0.74(0.55-0.94)$ & $1.03(0.95-1.10)$ \\
\hline
\end{tabular}

Some subterranean Termitidae, mainly from the subfamily Apicotermitinae (Table 1), that usually inhabit nests constructed by other termites (inquiline species) were also present (Torales, 1998). These inquiline species are not responsible for the construction of the nests in which they are found, but they excavate their own galleries and, apparently, there are no close interactions between building termites and inquiline species. More than one inquiline species can be found in a termite nest, mainly restricted to their subterranean portion.

According to its feeding habits (Table 1), some of the termites recorded at the three National Parks were strictly xilophagous, humivorous or feed on grass or dry dung from herbivorous mammals, but most of them feed on litter and woody decomposed materials (fallen trunks, branches, leaves) lying on the ground surface (Torales et al., 1997).These species are important in the decomposition of plant material in natural landscapes.

The Mburucuya National Park shares species with the other two areas, probably due to its particular characteristic of being situated at the convergence of three natural regions.

Because most of the collected termites were found at only one of the sampled National Parks, the results of this study suggest that the three protected areas are of considerable importance for the conservation of the termite assemblage for the Northeast region of the country.

\section{ACKNOWLEDGEMENTS}

To the Administración General de Parques Nacionales and Mr. Juan Carlos Chebez for the authorization to work at the protected areas. To the technical and professional staff at the Centro de Investigaciones Ecologicas Subtropicales (CIES) of the Iguassu National Park, to Mr. Carlos Saibene and Dr. Silvana Montanelli from the Mburucuya National Park and to Mr. Nestor Sucunza from the Chaco National Park, for providing accommodation and for their help during field work. To Y. Roisin and E. M. Cancello for identification of specimens of $N$. coxipoensis and $R$. rugosus, respectively. Supported by Secretaria General de Ciencia y Tecnica (UNNE).

\section{REFERENCES}

ALVAREZ, B.B.; AGUIRRE, R.; CÉSPEDEZ, J.A.; LIONS, M.L. Herpetofauna del Parque Nacional Mburucuyá (Corrientes, Argentina) Comunicaciones Cientificas y Tecnológicas de la UNNE, v.3, p.3538, 1998.

CABRERA, A.L. Regiones fitogeográficas argentinas. In: ENCICLOPEDIA ARGENTINA DE AGRICULTURA Y JARDINERIA. Buenos Aires: ACME, 1976. p.1-85.

CARNEVALI, R. Fitogeografía de la provincia de Corrientes. Corrientes: Gobierno de la Provincia de Corrientes; INTA, 1994. 324p.

CÉSPEDEZ, J.A.; LIONS, M.L.; SCHAEFER, E.F.; ALVAREZ, B.B. Herpetofauna del Parque Nacional Chaco, Provincia del Chaco, Argentina. Comunicaciones Cientificas y Tecnológicas de la UNNE, v.3, p.39-42, 1998. 
CODDINGTON, J.A.; GRISWOLD, C.E; DAVILA, D.S.; PENARANDA, E.; LARCHER, S.F. Designing and testing sampling protocols to estimate biodiversity in tropical ecosystems. In: INTERNATIONAL CONGRESS OF SYSTEMATIC AND EVOLUTIONARY BIOLOGY, 4., Portland, 1991. The unity of evolutionary biology; proceedings. Portland: Dioscorides Press, 1991. p.44-60.

CONSTANTINO, R. Catalog of the termites of the New World (Insecta: Isoptera). Arquivos de Zoologia, v.35, p.135-231, 1998.

CONSTANTINO, R. Chave ilustrada para identificaçao dos gêneros de cupins (Insecta: Isoptera) que ocorrem no Brasil. Papéis Avulsos de Zoologia, v.40, p.387-448, 1999.

CONSTANTINO, R. Key to the soldiers of South American Heterotermes with a new species from Brazil (Isoptera: Rhinotermitidae). Insect Systematics \& Evolution, v.31, p.463-472, 2000.

CONSTANTINO, R. An illustrated key to Neotropical genera (Insecta: Isoptera) based primarily on soldiers. ZOOTAXA, v.67, p.1-40, 2002.

COSCARÓN, S. Panorama sobre el conocimiento de la biodiversidad en la Argentina. Revista de la Sociedad Entomológica Argentina, v.58, p.132-136, 1999.

DILLON, W.R.; GOLDSTEIN, M. Multivariate analysis. Methods and applications. New York: John Wiley and Sons, 1984. 608p.

EGGLETON, P.; BIGNELL, D.E.; SANDS, W.A.; WAITE, B.; WOOD, T.G.; LAWTON, J.H. The species richness of termites (Isoptera) under differing levels of forest disturbance in the Mbalmayo Forest Reserve, southern Cameroon. Journal of Tropical Ecology, v.11, p.85-98, 1995.

EGGLETON, P.; BIGNELL, D.E.; SANDS, W.A.; MAWDSLEY, N.A.; LAWTON, J.H.; WOOD, T.G.; BIGNELL, N.C. The diversity, abundance and biomass of termites under differing levels of disturbance in the Mbalmayo Forest Reserve, southern Cameroon. Philosophical Transactions of the Royal Society of London, Series B, v.351, p.5168, 1996.

EMERSON, A.E. The Neotropical genera Procornitermes and Cornitermes (Isoptera, Termitidae). Bulletin of the American Museum of Natural History, v.99, p.475-539, 1952.

ERIZE, F.; CANEVARI, M.; CANEVARI, P.; COSTA, G.; RUMBOLL, M. Los Parques Nacionales de la Argentina y otras de sus áreas naturales. Madrid: INCAFO, 1981. 224p.

FONTES, L.R. Two new genera of soldierless Apicotermitinae from the Neotropical Region (Isoptera, Termitidae). Sociobiology, v.2, p.285-297, 1986.

FONTES, L.R. Key to the genera of New World Apicotermitinae (Isoptera: Termitidae). In: QUINTERO, D.A.; AIELLO, A. (Ed.) Insects of Panama and Mesoamerica. New York: Oxford University Press, 1992. p.242-248.

FONTES, L.R.; TERRA, P.S. A study on the taxonomy and biology of the Neotropical termite Nasutitermes aquilinus (Isoptera, Termitidae, Nasutitermitinae). Revista Brasileira de Entomologia, v.25, p.171$183,1981$.

JONES, D.T.; EGGLETON, P. Sampling termite assemblages in tropical forests: testing a rapid biodiversity assessment protocol. Journal of Applied Ecology, v.37, p.191-203, 2000.
KRISHNA, K. A generic revision and phylogenetic study of the family Kalotermitidae (Isoptera). Bulletin of the American Museum of Natural History, v.122, p.303-408, 1961.

LAFFONT, E.R.; TORALES, G.J.; ARBINO, M.O.; GODOY, M.C.; PORCEL, E.; CORONEL, J.M. Termites asociadas aEucalyptus grandis Hill ex Maiden en el Noreste de la provincia de Corrientes, Argentina. Revista de Agricultura, v.73, p.201-214, 1998.

MATHEWS, A.G. Studies on termites from the Mato Grosso State, Brazil. Rio de Janeiro: Academia Brasileira de Ciências, 1977. 267p.

SAIBENE, C.S.; MONTANELLI, S.B. Mapeo de las comunidades vegetales leñosas del Parque Nacional Mburucuya, Corrientes, Argentina. FACENA, v.13, p.49-57, 1997.

SILVESTRI, F. Contribuzione alla conoscenza dei Termiti e Termitofili dell' America Meridionale. Redia, v.1, p.1-234, 1903.

TORALES, G.J. Termites (Isoptera) que causan infestación en la Argentina. In: BERTI FILHO, E.; FONTES, L.R. (Ed.) Alguns aspectos atuais da biología e controle de cupins. Piracicaba: FEALQ, 1995. p.157-160.

TORALES, G.J. Isoptera. In: MORRONE, J.J.; COSCARÓN, S. Biodiversidad de artrópodos argentinos: una perspectiva biotaxonómica. La Plata: Ediciones Sur, 1998. cap.6, p.48-66.

TORALES, G.J.; LAFFONT, E.R.; ARBINO, M.O. Infestación de construcciones por Microcerotermes strunckii (Isoptera: Termitidae, Termitinae). Revista de la Asociación de Ciencias Naturales del Litoral, v.26, p.41-48, 1995a.

TORALES, G.J.; LAFFONT, E.R.; ARBINO, M.O. Termites que infestan construcciones en la provincia de Corrientes. Pest Report, v.14, p.7, $1995 b$.

TORALES, G.J.; LAFFONT, E.R.; ARBINO, M.O. Primera cita de infestación de construcciones por Nasutitermes fulviceps (Isoptera: Termitidae). Revista de la Asociación de Clencias Naturales del Litoral, v.27, p.62-65, 1996.

TORALES, G.J.; LAFFONT, E.R.; ARBINO, M.O.; GODOY, M.C. Primera lista faunística de los isópteros de la Argentina. Revista de la Sociedad Entomológica Argentina, v.56, p.47-53, 1997.

TORALES, G.J.; VENIALGO, C.A.; LAFFONT, E.R.; MARTEGANI, M.M.; ARMÚA, A.C.; ARBINO, M.O.; GODOY, M.C. Contribución al conocimiento de las termites de Argentina (Provincia de Corrientes). Termites xilófagas que infestan árboles de importancia económica. In: CONGRESO FORESTAL ARGENTINO, 6., Santiago del Estero, 1988. Actas. Santiago del Estero, 1988. v.3, p.733- 735.

TORALES, G.J.; OSCHEROV, E.B.; ARMÚA, A.C.; MARTEGANI, M.M.; LAFFONT, E.R.; ARBINO, M.O. Contribución al conocimiento de las termites de Argentina (provincia de Corrientes). Nasutitermes corniger Motschulsky (Isoptera: Termitidae, Nasutitermitinae). Infestación de viviendas. FACENA, v.8, p.9-25, 1990.

WOOD, T.G.; SANDS, W.A. The role of termites in ecosystems. In: BRIAN, M.V. (Ed.) Production ecology of ants and termites. Cambridge: Cambridge University Press, 1978. p.245 -292.

Received August 01, 2003

Accepted September 13, 2004 